\title{
A Laboratory Method to Estimate the Efficiency of Plant Extract to Neutralize Soil Acidity
}

\author{
Marcelo E. Cassiolato ${ }^{1}$; Mário Miyazawa ${ }^{2}$; Anderson R. Meda ${ }^{1}$ and Marcos A. Pavan ${ }^{2 *}$ \\ ${ }^{1}$ PIBIC / CNPq / IAPAR scholarship. ${ }^{2}$ Instituto Agronômico do Paraná (IAPAR); C. P. 481; CEP 86001-970; \\ Londrina - PR - Brasil
}

\begin{abstract}
Water-soluble plant organic compounds have been proposed to be efficient in alleviating soil acidity. Laboratory methods were evaluated to estimate the efficiency of plant extracts to neutralize soil acidity. Plant samples were dried at $65^{\circ} \mathrm{C}$ for $48 \mathrm{~h}$ and ground to pass $1 \mathrm{~mm}$ sieve. Plant extraction procedure was: transfer $3.0 \mathrm{~g}$ of plant sample to a becker, add $150 \mathrm{ml}$ of deionized water, shake for $8 \mathrm{~h}$ at $175 \mathrm{rpm}$ and filter. Three laboratory methods were evaluated: $\Sigma(\mathrm{Ca}+\mathrm{Mg}+\mathrm{K})$ of the plant extracts; electrical conductivity of the plant extracts and titration of plant extracts with $\mathrm{NaOH}$ solution between $\mathrm{pH} 3$ to 7 . These methods were compared with the effect of the plant extracts on acid soil chemistry. All laboratory methods were related with soil reaction. Increasing $\Sigma(\mathrm{Ca}+\mathrm{Mg}+\mathrm{K})$, electrical conductivity and the volume of $\mathrm{NaOH}$ solution spent to neutralize $\mathrm{H}^{+}$ion of the plant extracts were correlated with the effect of plant extract on increasing soil pH and exchangeable Ca and decreasing exchangeable Al. It is proposed the electrical conductivity method for estimating the efficiency of plant extract to neutralize soil acidity because it is easily adapted for routine analysis and uses simple instrumentations and materials.
\end{abstract}

Key words: Plant residue, organic acid, plant alkaline index

\section{INTRODUCTION}

Plant residues release a range of low molecular weight organic acids such as maleic, citric, oxalic, salicylic, etc, which are involved in many soil processes including lime mobility (Ziglio et al., 1999; Miyazawa et al., 1998), metal organic complexing reactions (Franchini et al., 1999 and 2001), ion sorption (Bolan et al., 1994) and rhizosphere chemistry (Jones, 1998). These organic acids contain carboxyl and phenolic groups, thereby allowing the cation complexation reaction and the anion competition for a soil adsorption sites.
The ability of organic acids for cation complexation in solution is well established (Hue et al., 1986; Miyazawa et al., 1992) and has being attributed to the presence of the negative charges in the functional groups. Complexing formation depends on the number and the position of carboxyl and phenolic functional groups in the organic acids.

The composition of organic acids in plants is well documented (Curl \& Trueglove, 1986; Aoyama, 1996). Using high performance size exclusion chromatography (Aoyama, 1996) and semiquantitative techniques (Curl \& Trueglove, 1986), they observed that the composition of organic acids in plants are highly variable and depends on

\footnotetext{
${ }^{*}$ Author for correspondence
} 
plant species, plant age and physiochemical environment. Despite of this early works, however, the effects of plant organic acids on soil chemistry have only recently started to be elucidated (Miyazawa et al., 1998; Ziglio et al., 1999; Franchini et al., 1999; Meda et al., 1999). In general, these authors concluded that several plant residues are highly efficient in alleviating soil acidity.

The objectives of this work were to develop a laboratory method to evaluate the efficiency of water extracts of plant residues to neutralize soil acidity and to evaluate the most appropriate method for laboratory routine.

\section{MATERIALS AND METHODS}

Plant materials: black oats (Avena strigosa), oil seed radish (Raphanus sativus), white lupin (Lupinus albus), gray mucuna (Stizolobium cinereum), wheat straw (Triticum aestivum). The aereal parts of the black oats, oil seed radish, white lupin and gray mucuna were collected at flowering stage and wheat straw after grain's harvest.

Water plant extract: $3 \mathrm{~g}$ of dried plant material (aereal parts) were transferred to a plastic flask, added $150 \mathrm{ml}$ of deionized water, shaked for $8 \mathrm{~h}$ at $175 \mathrm{rpm}$ and filtrated. Sub samples of plant extracts were used for chemical analysis (Table 1). Basic cations ( $\mathrm{Ca}, \mathrm{Mg}$, and $\mathrm{K}$ ) were determined by ICP (Inductively Coupled Plasma).

Experiment with soil: acid soil sample taken from the $0-20 \mathrm{~cm}$ horizon was air-dried and passed through a $2 \mathrm{~mm}$ sieve. The soil had an original $\mathrm{pH}$ $\mathrm{CaCl}_{2}$ value of 4.10 ; exchangeable $\mathrm{Ca}, \mathrm{Mg}, \mathrm{K}$, and $\mathrm{Al}$ contents of $0.37,0.17,0.05$, and $1.11 \mathrm{cmol}_{\mathrm{c}} \mathrm{dm}^{-}$ ${ }^{3}$, respectively, total acidity $(\mathrm{H}+\mathrm{Al})$ of $6.20 \mathrm{cmol}_{\mathrm{c}}$ $\mathrm{dm}^{-3}$, and total carbon content of $7.64 \mathrm{~g} \mathrm{~kg}^{-1}$. The clay content was $27 \%$, silt $2 \%$ and sand $71 \%$. Soil sample was transferred to PVC column $(30 \mathrm{~cm}$ high by $4 \mathrm{~cm}$ diameter) and compacted to a homogeneous bulk density (mean $1 \mathrm{~g} \mathrm{~cm}^{-3}$ ). Plant extract solution $(150 \mathrm{ml})$ in amount equivalent to one porous volume $(\mathrm{pV})$ was added on the soil surface. Then, deionized water was added in amount equivalent to three $\mathrm{pV}$, to a total of 450 $\mathrm{ml}$. Plant extract and water were added at a rate of $1.0 \mathrm{ml} \mathrm{min}{ }^{-1}$. Soil samples were collected at 0-5, 5$10,10-15,15-20$ and 20-25 cm depth, air-dried, ground to pass $2 \mathrm{~mm}$ sieve and analyzed for $\mathrm{pH}$
$\mathrm{CaCl}_{2}$ and exchangeable $\mathrm{Al}_{\mathrm{ex}}$ and $\mathrm{Ca}_{\mathrm{ex}}$. Extraction and determination methods were described by Pavan et al. (1992). All treatments had three replicates in a completely randomized block design.

\section{Laboratory methods:}

1. Summation of basic cations $[\Sigma(\mathrm{Ca}+\mathrm{Mg}+$ K)]: sum of $\mathrm{Ca}, \mathrm{Mg}$, and $\mathrm{K}$ contents in the plant extract solution (Table 1).

2. Electrical conductivity (EC): measured with electrode installed into a becker containing a $10 \%$ diluted plant extract in deionized water at $25^{\circ} \mathrm{C}$.

3. Capacity to reduce $\mathrm{H}^{+}$ion: transfer $25 \mathrm{ml}$ of plant extract to a becker, set up a $\mathrm{H}^{+}$ion selective electrode into the becker, adjust to $\mathrm{pH} 3.0$ with 2 mol L L $\mathrm{HCl}$ solution, titrate with $0.05 \mathrm{~mol} \mathrm{~L}^{-1}$ $\mathrm{NaOH}$ solution to $\mathrm{pH} 7.0$, and register the volume of $0.05 \mathrm{~mol} \mathrm{~L}^{-1} \mathrm{NaOH}$ spent. The pHs 3.0 and 7.0 were selected due to the maximum protonation and deprotonation, respectively, of the organic anions (Young et al., 1981).

\section{RESULTS AND DISCUSSION}

The $\mathrm{pH}, \mathrm{Ca}_{\mathrm{ex}}$, and $\mathrm{Al}_{\mathrm{ex}}$ by depth for the control and plant extract treatments are shown in figures 1,2 , and 3, respectively. Control soil had lower $\mathrm{pH}$ and $\mathrm{Ca}_{\mathrm{ex}}$ and higher $\mathrm{Al}_{\mathrm{ex}}$ contents. Additions of plant extracts increased soil $\mathrm{pH}$ and $\mathrm{Ca}_{\mathrm{ex}}$ and decreased $\mathrm{Al}_{\mathrm{ex}}$, corroborating data presented in early studies with brazilian acid soils (Miyazawa et al., 1993 and 1998; Franchini et al., 1999 and 2000; Meda et al., 1999). These results show that the effect of plant extracts on soil acidity was highly variable and depended on plant species. In general, the effect of plant extract on soil acidity followed the order: oil seed radish $>$ black oats $>$ lupin $>$ mucuna $>$ wheat straw. Oil seed radish, black oats and lupin increased $\mathrm{pH}$ up to $20 \mathrm{~cm}$ soil depth. Oil seed radish and black oats neutralized totally $\mathrm{Al}_{\mathrm{ex}}$ up to $10 \mathrm{~cm}$ soil depth and partially up to $25 \mathrm{~cm}$ soil depth. Except for wheat straw, the other plant extracts increased $\mathrm{Ca}_{\mathrm{ex}}$ in the soil profile. Black oats and oil seed radish showed the greatest increment on $\mathrm{Ca}_{e x}$ in the soil profile. Oil seed radish was the most efficient to increase the total $\mathrm{Ca}_{\mathrm{ex}}$ in the soil column. These results indeed 
support the view the soluble organic compounds as short chain fatty acids in soil are mobile and efficient in alleviating soil acidity (Franchini et al., 2001).

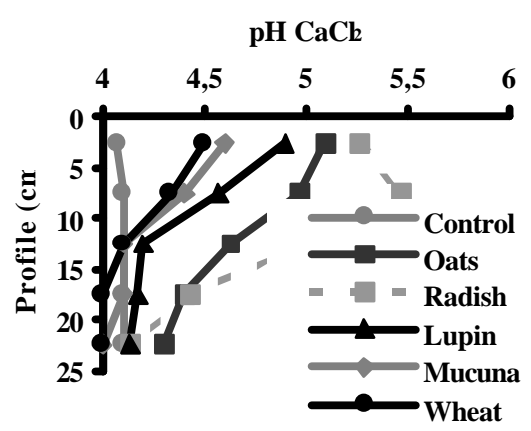

Figure 1 - Effect of plant extracts on soil $\mathrm{pH}$.

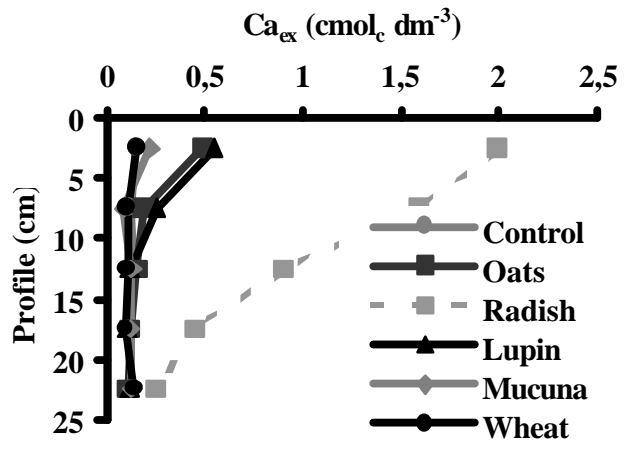

Figure 2 - Effect of plant extracts on soil $\mathrm{Ca}_{\mathrm{ex}}$.

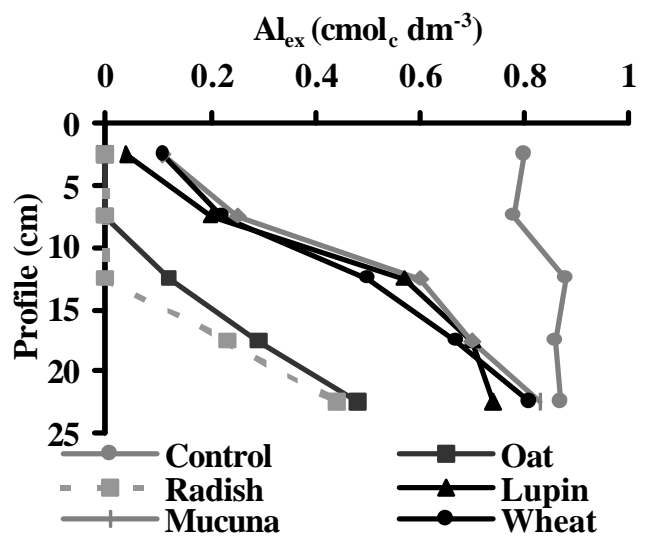

Figure 3 - Effect of plant extracts on soil Alex.

Table 1 shows the $\Sigma(\mathrm{Ca}+\mathrm{Mg}+\mathrm{K})$, the volume of $\mathrm{NaOH}$ spent during titration and the electrical conductivity of the plant extracts. The total amount of basic cations, the volume of $\mathrm{NaOH}$ spent, and the values of electrical conductivity followed the order: oil seed radish $>$ black oats $>$ mucuna $>$ lupin $>$ wheat straw. This is the same order found for alleviating soil acidity (Figures 1, 2 , and 3). Table 2 shows the regression equations and the correlation coefficients for soil $\mathrm{pH}, \mathrm{Al}_{\mathrm{ex}}$ and $\mathrm{Ca}_{\mathrm{ex}}$ vs the three laboratory methods tested. These methods were highly correlated with soil parameters indicating that they can be used to estimate the efficiency of plant extract to neutralize soil acidity

Table 1 - Chemical composition of the plant extracts, volume of $\mathrm{NaOH}$ spent between $\mathrm{pH} 3$ to 7 , and the $\mathrm{EC}$ of the plant extract

\begin{tabular}{|c|c|c|c|}
\hline Plant extract ${ }^{1}$ & $\begin{array}{l}\text { Composition } \\
\text { ( } \text { cations) } \\
\text { mmol } \mathrm{L}^{-1}\end{array}$ & $\begin{array}{c}\mathrm{NaOH} \\
\text { volume }^{2} \\
\mathrm{ml}\end{array}$ & $\mathrm{EC}$ \\
\hline Black oats & 27.6 & 11.6 & $\begin{array}{c}5,87 \\
0\end{array}$ \\
\hline $\begin{array}{ll}\text { Oil } & \text { seed } \\
\text { radish } & \end{array}$ & 40.3 & 14.4 & $\begin{array}{c}6,68 \\
0\end{array}$ \\
\hline Mucuna & 10.4 & 6.4 & $\begin{array}{c}2,36 \\
0\end{array}$ \\
\hline Lupin & 13.9 & 10.0 & $\begin{array}{c}3,20 \\
0\end{array}$ \\
\hline Wheat straw & 2.1 & 6.0 & $\begin{array}{c}2,12 \\
0\end{array}$ \\
\hline
\end{tabular}

Table 2 - Regression equations and correlation coefficient for $\mathrm{pH}, \mathrm{Al}$ and $\mathrm{Ca}$ vs $\sum$ cations, EC and the volume of $\mathrm{NaOH}$ spent during titration coefficients for soil $\mathrm{pH}, \mathrm{Ca}_{\mathrm{ex}}$ and $\mathrm{Al}_{\mathrm{ex}}$ vs the three laboratory methods tested.

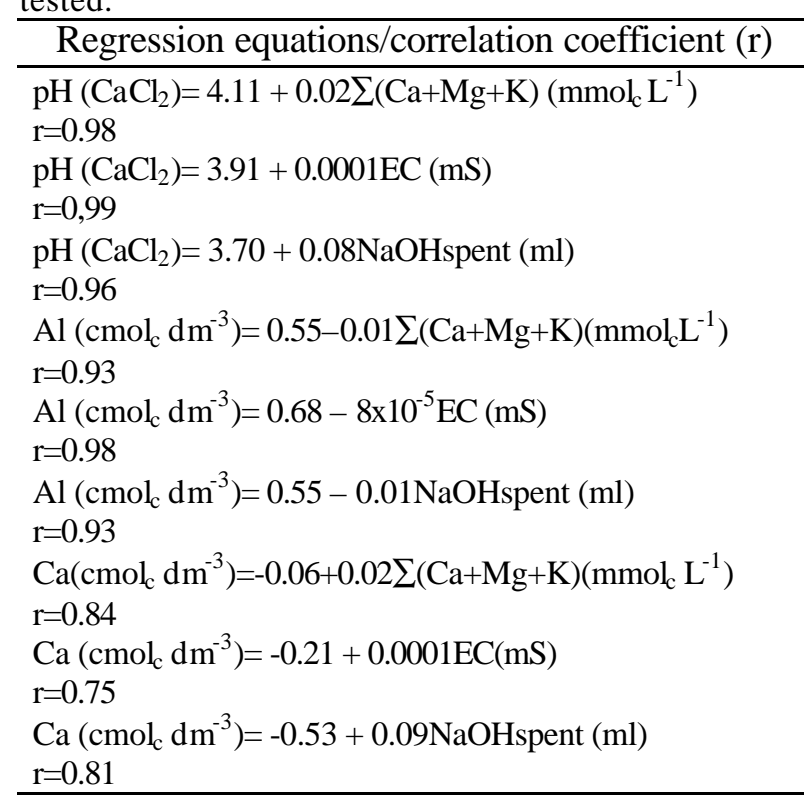


The greater amount of $\mathrm{NaOH}$ used, the higher content of basic cations and the higher electrical conductivity of the oil seed radish and black oats than wheat straw extract indicated a higher alkaline capacity of the oil seed radish and black oats. Due to its simplicity (instrumentation and materials) and for being easily adapted for routine analysis it is recommended the electrical conductivity method for estimating the efficiency of the plant extract to neutralize soil acidity.

\section{CONCLUSION}

The efficiency of plant extract $\mathbf{b}$ neutralize soil acidity can be estimated in the laboratory by sum of $\mathrm{Ca}, \mathrm{Mg}$, and $\mathrm{K}$, the volume of $\mathrm{NaOH}$ solution spent between $\mathrm{pH} 3$ to 7 , and the electrical conductivity of the plant extracts. Due to its simplicity it is recommended the electrical conductivity method.

\section{RESUMO}

Tem sido proposto que os compostos orgânicos de plantas solúveis em água são eficientes na amenização da acidez do solo. Foram avaliados métodos de laboratório para estimar a eficiência dos extratos de plantas na neutralização da acidez do solo. Os materiais de plantas foram secos a $65^{\circ}$ C por 48 horas, moídos e passados em peneira de $1 \mathrm{~mm}$. Utilizou-se o seguinte procedimento para obtenção do extrato de plantas: transferir $3.0 \mathrm{~g}$ da amostra de planta para um becker, adicionar 150 $\mathrm{ml}$ de água deionizada, agitar por $8 \mathrm{~h}$ a $175 \mathrm{rpm}$ e filtrar. Avaliaram-se três métodos de laboratório: $\Sigma(\mathrm{Ca}+\mathrm{Mg}+\mathrm{K})$ do extrato de planta, condutividade elétrica (CE) do extrato de planta e titulação do extrato de planta com solução de $\mathrm{NaOH}$ entre $\mathrm{pH} 3$ a 7. Os métodos de laboratório foram comparados com o efeito dos extratos de plantas na reação do solo. Todos os métodos de laboratório foram correlacionados com a reação do solo: o aumento de $\Sigma(\mathrm{Ca}+\mathrm{Mg}+\mathrm{K})$, Ce e o volume de $\mathrm{NaOH}$ gasto para neutralizar os íons $\mathrm{H}^{+}$ do extrato de plantas, foram correlacionados com o efeito nos aumentos de $\mathrm{pH}$ e Ca trocável e diminuição de $\mathrm{Al}$ trocável do solo. É proposto o método de CE para estimar a eficiência do extrato de plantas na neutralização da acidez do solo por ser facilmente adaptado para análise de rotina e por utilizar instrumentos e materiais simples.

\section{REFERENCES}

Aoyama, M. (1996), Fractionation of water-soluble organic substances formed during plant residue decomposition and high performance size exclusion chromatography of the fractions. Soil Sci. Pl. Nutr., 42, 31-40.

Boln, N. S.; Naidu, R.; Mahimairaja, S. and Baskaran, S. (1994), Influence of low-molecular-weight organic acids on the solubilization of phosphates. Biol. Fertil. Soils, 18, 311-319.

Curl, E. and Trueglove, B. (1986), The rhizosphere. Berlin, Springer-Verlag.

Franchini, J. C.; Malavolta, E.; Miyazawa, M. and Pavan, M. A. (1999), Alterações químicas em solos ácidos após a aplicação de resíduos vegetais. $R$. bras. Ci. Solo, 23, 533-542.

Franchini, J. C.; Gonzalez-Vila, F. J.; Cabrera, F.; Miyazawa, M. and Pavan, M. A. (2001), Rapid transformations of plant water-soluble organic compounds in relation to cation mobilization in an acid oxisol. Pl. Soil, 1-9.

Hue, N. V.; Craddock, G. R. and Adams, F. (1986), Effect of organic acids on aluminum toxicity in subsoils. Soil Sci. Soc. Am. J., 50, 28-34.

Jones, D. L. (1998), Organic acids in the Rhizosphere a critical review. Pl. Soil, 205, 25-44.

Meda, A. R.; Cassiolato, M. E.; Miyazawa, M. and Pavan, M. A. (1999), Plant extracts to improve acid soil chemistry. In - CONGRESSO LATINO AMERICANO DE LA CIENCIA DEL SUELO, 14., Temuco, Universidade de la Fronteira. pp. 360.

Miyazawa, M.; Pavan, M. A. and Franchini, J. C. (1998), Organic mobility of surface applied lime under no-tillage. In - INTERNATIONAL MEETING OF THE INTERNATIONAL HUMIC SUBSTANCE SOCIETY, 9., Adelaide, IHSS. pp. 166.

Miyazawa, M.; Chierice, G. O. and Pavan, M. A. (1992), Amenização da toxidade de alumínio às raízes do trigo pela complexação com ácidos orgânicos. R. bras. Ci. Solo, 16, 209-215.

Miyazawa, M.; Pavan, M. A. and Calegari, A. (1995), Efeito de material vegetal na acidez do solo. Rev. Bras. Ci. Solo, 17, 411-416.

Pavan, M. A.; Bloch, M. F.; Zempulski, H. D.; Miyazawa, M. and Zocoler, D. C. (1992), Manual de análise química do solo e controle de qualidade. Londrina, Instituto Agronômico do Paraná, 40 pp. (IAPAR Circular; 76).

Young, S. D.; Bache, B. W.; Welch, D. and Anderson, H. A. (1981), Analysis of the potentiometric titration of natural and synthetic poly-carboxylates. Soil Sci., 32, 579-592. 
Ziglio, C. M.; Miyazawa, M. and Pavan, M. A. (1999), Organic and inorganic forms of calcium mobilization in soil. Arq. Biol. Tecnol., 42 : (2), 257-262.

Received: December 29, 2000; Revised: March 09, 2001; Accepted: August 28, 2001. 


\title{
PÁGINA
}

\author{
EM
}

BRANCO 